Dhaka Univ. J. Biol. Sci. 29(1): 1-8, 2020 (January)

\title{
EFFECTS OF TRICHODERMA-ENRICHED BIOFERTILIZER AND FARMYARD MANURE ON THE GROWTH AND YIELD OF BRINJAL (SOLANUM MELONGENA L.)
}

\author{
SONIA Hossain* AND FARJAna AKTER \\ Department of Soil, Water and Environment, University of Dhaka, Dhaka-1000, Bangladesh \\ Key words: Trichoderma biofertilizer, Farmyard manure, Yield components, Brinjal
}

\begin{abstract}
A pot experiment was carried out to assess the comparative effects of Trichoderma-enriched biofertilizer and farmyard manure on the growth and yield components of brinjal (Solanum melongena L.). The treatments were $\mathrm{T}_{0}$ (control), $\mathrm{T}_{1}$ (Trichoderma-enriched biofertilizer $5 \mathrm{t} /$ ha), $\mathrm{T}_{2}$ (Trichoderma-enriched biofertilizer $10 \mathrm{t} / \mathrm{ha}$ ), $\mathrm{T}_{3}$ (Trichoderma- enriched biofertilizer $15 \mathrm{t} / \mathrm{ha}$ ), $\mathrm{T}_{4}$ (Farmyard manure 5 $\mathrm{t} / \mathrm{ha}$ ), $\mathrm{T}_{5}$ (Farmyard manure $10 \mathrm{t} / \mathrm{ha}$ ) and $\mathrm{T}_{6}$ (Farmyard manure $15 \mathrm{t} / \mathrm{ha}$ ). The experiments were laid out in completely randomized design (CRD) with three replications of each treatment. Among the different treatments $\mathrm{T}_{3}$ showed best as much as twice more effective than farmyard manure in increasing growth and yield parameters (plant height, fruit length, fresh weight and dry weight of stem, leaf and fruit) of brinjal plants. Overall, all the treatments increased macronutrients and micronutrients content and uptake by brinjal plants over control. Analysis of post-harvest soil samples also revealed that all the parameters except $\mathrm{pH}$ were increased due to different treatments.
\end{abstract}

\section{Introduction}

In recent time, it has been realized that the alternative to chemical fertilizers may be organic and biofertilizer which can help in enhancing the yield and concomitantly reduce the harm inflicted by the use of chemical fertilizers ${ }^{(1)}$. Biodiversity, biological cycles and soil biological activity are also enhanced which in turn helps to achieve optimal natural systems that are socially, ecologically and economically sustainable ${ }^{(2)}$. Trichoderma (fungal genus) is among the microorganisms presently marketed as active ingredient of biofertilizer, bio-fungicide, growth enhancer and stimulant of natural resistance. They have been found to increase the growth and yield of plants. They also increase the survival of seedlings, plant height, leaf area and dry weight. Trichoderma species was found to improve the uptake of minerals; increase the efficiency of nitrogen use, enhance the efficiency of photosynthesis and solubilization of nutrients like phosphorus and iron in soil and organic matter; enhance the production of plant hormone, induce systematic

*Author for correspondence: <soniahossain_ng@yahoo.com>. 
resistance mechanisms, and induce root systems in hydroponics ${ }^{(3-6)}$. Moreover, the introduction of Trichoderma strains with or without pathogens did not affect the existing soil beneficial populations. For these reasons Trichoderma species are known as plant growth promoting fungi or biofertilizer. On the other hand, farmyard manure has been used as a soil conditioner since ancient times. It supplies all major as well as micronutrients necessary for plant growth and enhances crop production. Hence, it acts as a mixed fertilizer and improves the physical, chemical and biological properties of soil ${ }^{(7)}$.

Brinjal (Solanum melongena L.) is a versatile crop adapted to different agro-climatic regions. It is grown under field and greenhouse conditions in almost all countries in the world. Keeping the above stated facts in view, the present study was conducted using a recently reclaimed soil to evaluate the effects of Trichoderma-enriched biofertilizer and farmyard manure on growth and yield of brinjal. The availability of nutrients to the plants and the changes in soil properties were also assessed.

\section{Materials and Methods}

The pot experiment was carried out in the net house of the Department of Soil, Water and Environment, University of Dhaka, Bangladesh from June 2016 to September, 2016. The experiment was laid out in completely randomized design (CRD) with 3 replications each. Trichoderma-enriched biofertilizer and farmyard manure were applied in the soil each at three rates $(5,10$ and $15 \mathrm{t} / \mathrm{ha})$, which were designated as $\mathrm{T}_{1}, \mathrm{~T}_{2}, \mathrm{~T}_{3}, \mathrm{~T}_{4}, \mathrm{~T}_{5}$ and $\mathrm{T}_{6}$, respectively. The control of the experiment was designated as. T0, where soil was not supplied with any biofertilizer or manure. Earthen pots (5 kg in size) were first washed, dried and marked in accordance with the treatments. The soil used in this study was made up of two problemetic soils, namely acid and calcareous. The soils were collected from two different locations, location 1 being Binnapara village, Chehelgazi union, Dinajpur Sadar Upazilla of Dinajpur district (AEZ-1) and location 2 being from West Gangabardi village, Krishnanagar union, Faridpur Sadar Upazilla of Faridpur district (AEZ-12). Soils were mixed thoroughly for reclamation purposes and reclamation process was found to be successful from the study(8).

Trichoderma-enriched biofertilizer was collected from the Centre for Advanced Research in Sciences (CARS) of Dhaka University. The composition of $1 \mathrm{~kg}$ Trichodermaenriched biofertilizer was: Peat soil $350 \mathrm{gm}$, rotten sugarcane bagasse $150 \mathrm{gm}$, rice bran 150 gm, mustard bran 100 gm, sandy loam soil 250 gm, Trichoderma spp. 109 CFU (colony forming unit)/g. On the other hand, farmyard manure was collected from a farm house at Kapasia Upazilla in Gazipur district. It was mainly made up of decomposed dung and urine of farm animals along with their litter and left over material from roughages or fodder fed to the cattle. The physico-chemical properties of Trichoderma-enriched biofertilizer and farmyard manure are given in Table 1. 
Collected Trichoderma-enriched biofertilizer and farmyard manure along with soil were air-dried, passed through $2 \mathrm{~mm}$ sieve and prepared for chemical analysis. Digestion of soil sample, biofertilizer and manure was done using aqua-regia $\left(\mathrm{HCl}: \mathrm{HNO}_{3}=3: 1\right)$ and total nutrient content was determined by wet oxidation method (OC), microKjeldhal method (total $\mathrm{N}$ ), colorometric method ${ }^{(10)}$ using spectrophotometer $(\mathrm{P})$, flame photometer $(\mathrm{K}, \mathrm{Na})$ and atomic absorption spectrometer $(\mathrm{Ca}, \mathrm{Mg}, \mathrm{Fe}, \mathrm{Mn}, \mathrm{Zn})$.

Table 1. Properties of the soil, Trichoderma-enriched biofertilizer and farmyard manure.

\begin{tabular}{|c|c|c|c|}
\hline Physical properties & Soil & Trichoderma-biofertilizer & Farm yard manure \\
\hline Color & & Light brown to brown & Dark grey to black \\
\hline Physical condition & & Non-granular form & Non-granular form \\
\hline Odour & & Presence of foul odour & Presence of foul odour \\
\hline Texture & Loam & & \\
\hline \multicolumn{4}{|l|}{ Chemical properties } \\
\hline $\mathrm{pH}$ & 6.2 & 6.8 & 7.4 \\
\hline $\mathrm{EC}(\mu \mathrm{S} / \mathrm{cm})$ & 311 & & \\
\hline Organic carbon $(\%)$ & 1.10 & 23.8 & 19.7 \\
\hline $\mathrm{CEC}(\mathrm{cmol} / \mathrm{kg})$ & 9.60 & & \\
\hline $\mathrm{N}(\mathrm{mg} / \mathrm{kg})$ & $163^{a}$ & $17800^{\mathrm{T}}$ & $13600^{\mathrm{T}}$ \\
\hline $\mathrm{P}(\mathrm{mg} / \mathrm{kg})$ & $28^{a}$ & $2830^{\mathrm{T}}$ & $2303^{\mathrm{T}}$ \\
\hline $\mathrm{K}(\mathrm{mg} / \mathrm{kg})$ & $107^{a}$ & $8279^{\mathrm{T}}$ & $10785^{\mathrm{T}}$ \\
\hline $\mathrm{S}(\mathrm{mg} / \mathrm{kg})$ & $25^{\mathrm{a}}$ & $9238^{\mathrm{T}}$ & $7568^{\mathrm{T}}$ \\
\hline $\mathrm{Ca}(\mathrm{mg} / \mathrm{kg})$ & $1247^{a}$ & $4975^{\mathrm{T}}$ & $4350^{\mathrm{T}}$ \\
\hline $\mathrm{Mg}(\mathrm{mg} / \mathrm{kg})$ & $196^{\mathrm{a}}$ & $2997^{\mathrm{T}}$ & $2169^{\mathrm{T}}$ \\
\hline $\mathrm{Fe}(\mathrm{mg} / \mathrm{kg})$ & $67^{a}$ & $231^{\mathrm{T}}$ & $679^{\mathrm{T}}$ \\
\hline $\operatorname{Mn}(\mathrm{mg} / \mathrm{kg})$ & $29^{a}$ & $293^{\mathrm{T}}$ & $242^{\mathrm{T}}$ \\
\hline $\mathrm{Zn}(\mathrm{mg} / \mathrm{kg})$ & & $53^{\mathrm{T}}$ & $28^{\mathrm{T}}$ \\
\hline
\end{tabular}

aindicates available content, Tindicates total content.

About 20 days old seedlings of brinjal (local variety) were collected from a horticulture center situated at Gulshan-2 in Dhaka. The recommended doses of fertilizers for the growth of brinjal were added to each pot according to the Fertilizer Recommendation Guide ${ }^{(9)}$ where NPKS were supplied in the form of urea, TSP, MP and gypsum, respectively. Then, two seedlings were transplanted in each of the pot. After 10 - 12 days of transplantation, the better one between the two seedlings was kept in each pot and allowed to grow. The pots were properly watered to maintain optimum moisture for plant growth. Weeds were removed manually. Adequate plant protection measures were taken during the growing period. After 80 days of transplantation (when yellowish tint appeared in some fruits), stem, leaf and fruit samples were collected separately from each pot, washed with tap water and blotted dry with paper towel. The heights of the collected plants and lengths of fruits were recorded. The fresh weights of stem, leaf and fruits were taken separately with an electric balance. The samples were then first air- 
dried and then oven-dried at $70^{\circ} \pm 5^{\circ} \mathrm{C}$ for 48 hours and dry weights of the samples were taken. The oven dried samples were ground with mortar and pestle. The ground samples were then digested using nitric (70\%)-perchloric $(70 \%)$ acid. The nutrient contents were analyzed with spectrophotometer, flame photometer, atomic absorption spectrometer following standard methods.

The data collected in the experiments were calculated and results were graphically presented by using Microsoft Excel (version 2007). The calculated results were statistically analyzed in the form of one-way analysis of variance (ANOVA) by using SPSS (version 20) software.

\section{Results and Discussion}

Height of brinjal plants ranged from 48 to $57 \mathrm{~cm}$ (Table 2) in response to different treatments. The highest plant height was recorded in treatment $\mathrm{T}_{3}$ and the second highest $(56.5 \mathrm{~cm})$ in treatment $\mathrm{T}_{2}$ compared to the lowest observed in control, $\mathrm{T}_{0}$. Treatment $\mathrm{T}_{6}$ performed better than other farmyard manure treatment but lower than two Trichoderma treatments. Plant height was found to be increased over control for $\mathrm{T}_{1}, \mathrm{~T}_{2}, \mathrm{~T}_{3}$ and $\mathrm{T}_{6}$.

The maximum fruit length $\left(18 \mathrm{~cm}\right.$ ) (Fig. 1) was also observed in $\mathrm{T}_{3}$ followed by $\mathrm{T}_{6}, \mathrm{~T}_{2}$, $\mathrm{T}_{5}$ and $\mathrm{T}_{1}$. The minimum fruit length $(9.5 \mathrm{~cm})$ was observed in $\mathrm{T}_{4}$ which was even lower than the control. Treatments $T_{2}, T_{3}, T_{5}$ and $T_{6}$ significantly increased fruit length over control. Studies with some vegetable crops showed that Trichoderma enhances root and shoot growth over control as much as up to $80 \%{ }^{(11,12)}$ which was also reflected in present study. Several mechanisms by which Trichoderma spp. may influence plant development, such as production of growth hormones, solubilization of insoluble micronutrients in soil and increased uptake and translocation of less-available minerals and control of minor pathogens ${ }^{(13,14)}$.

No significant differences were observed among the treatments in terms of fresh and dry weight. However, the fresh weight of stem and leaf slightly increased in all the treatments over control, $\mathrm{T}_{3}$ treatment having maximum fresh weight (Table 2). The dry weight of stem and leaf of brinjal plants followed the similar trend of fresh weight of stem and leaf with $T_{3}$ having the maximum and control having the minimum dry weight. On the other hand, all the treatments significantly increased fresh and dry weight of fruit over control, except for treatment $\mathrm{T}_{4}$. The maximum fresh and dry weight of fruit was observed in treatment $\mathrm{T}_{3}$. The fresh and dry weight of fruits followed the similar trend of response to the different treatments where $\mathrm{T}_{3}$ with $345 \%$ increases over control being the best treatment and $\mathrm{T}_{2}$ with $169 \%$ increases over control and $\mathrm{T}_{6}$ with $156 \%$ increases over control being close to $2^{\text {nd }}$ and $3^{\text {rd }}$ best treatment in terms of fruit growth and yield. These results showed that under similar condition, Trichoderma- \enriched biofertilizer is almost twice more effective than the farmyard manure in terms of fruit yield. Vegetative growth (stem and leaf) and biomass of the plants showed slightly differential response 
than reproductive growth which can be contributed to the differential nutrient uptake or content in plant leaf, stem and fruit (Table 3).

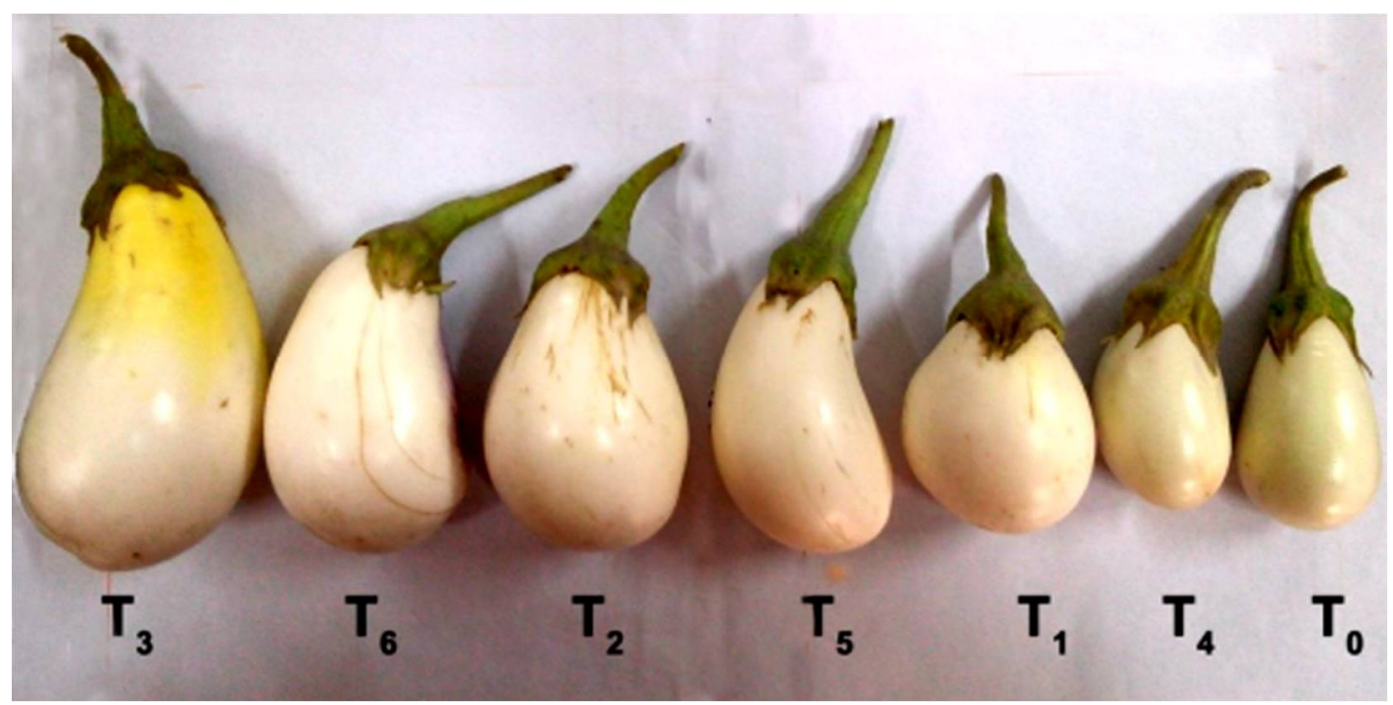

Fig. 1. Fruit length of brinjal in response to different treatments.

Table 2. Effects of Trichoderma-enriched biofertilizer and farmyard manure on the growth and yield parameters of brinjal.

\begin{tabular}{|c|c|c|c|c|c|c|c|c|c|c|c|c|}
\hline \multirow{2}{*}{$\begin{array}{l}\text { Treat- } \\
\text { ment }\end{array}$} & \multirow{2}{*}{$\begin{array}{c}\text { Av. } \\
\text { plant ht. } \\
(\mathrm{cm})\end{array}$} & \multirow{2}{*}{$\begin{array}{c}\text { IOC }^{*} \\
(\%)\end{array}$} & \multirow{2}{*}{$\begin{array}{l}\text { Fruit } \\
\text { length } \\
(\mathrm{cm})\end{array}$} & \multirow{2}{*}{$\begin{array}{c}\text { IOC }^{*} \\
(\%)\end{array}$} & \multicolumn{4}{|c|}{ Fresh weight (t/ha) } & \multicolumn{4}{|c|}{ Dry weight (t/ha) } \\
\hline & & & & & $\begin{array}{c}\text { Stem }+ \\
\text { leaf }\end{array}$ & $\begin{array}{c}\text { IOC }^{*} \\
(\%)\end{array}$ & Fruit & $\begin{array}{c}\text { IOC }^{*} \\
(\%)\end{array}$ & $\begin{array}{l}\text { Stem } \\
+ \text { leaf }\end{array}$ & $\begin{array}{c}\text { IOC }^{*} \\
(\%)\end{array}$ & Fruit & $\begin{array}{c}\text { IOC }^{*} \\
(\%)\end{array}$ \\
\hline $\mathrm{T}_{0}$ & 48.0 & & 10.0 & & 34.9 & & 13.6 & & 4.8 & & 1.9 & \\
\hline $\mathrm{T}_{1}$ & 55.0 & 14.6 & 11.0 & 10.0 & 36.1 & 3.3 & 25.3 & 86.5 & 5.3 & 10.7 & 3.8 & 95.8 \\
\hline $\mathrm{T}_{2}$ & 56.5 & 17.7 & 13.0 & 30.0 & 36.9 & 5.7 & 37.9 & 178.9 & 5.9 & 24.0 & 5.2 & 169.3 \\
\hline $\mathrm{T}_{3}$ & 57.0 & 18.8 & 18.0 & 80.0 & 38.7 & 10.8 & 62.9 & 363.0 & 6.2 & 30.1 & 8.6 & 345.3 \\
\hline $\mathrm{T}_{4}$ & 52.5 & 9.4 & 9.5 & -5.0 & 35.8 & 2.3 & 13.4 & -1.4 & 5.1 & 6.5 & 1.8 & -4.2 \\
\hline $\mathrm{T}_{5}$ & 49.0 & 2.1 & 12.5 & 25.0 & 36.0 & 3.0 & 28.2 & 107.4 & 5.1 & 7.6 & 4.0 & 108.9 \\
\hline $\mathrm{T}_{6}$ & 53.0 & 10.4 & 14.0 & 40.0 & 37.0 & 6.0 & 35.4 & 160.8 & 6.0 & 26.7 & 4.9 & 156.8 \\
\hline LSD & 4.59 & & 1.48 & & NS & & 5.04 & & 0.982 & & 0.77 & \\
\hline
\end{tabular}

*IOC $=$ increase over control. (Where, $\mathrm{T}_{0}=$ Control, $\mathrm{T}_{1}=$ Trichoderma- enriched biofertilizer $5 \mathrm{t} / \mathrm{ha}, \mathrm{T}_{2}=$ Trichoderma-enriched biofertilizer $10 \mathrm{t} / \mathrm{ha}, \mathrm{T}_{3}=$ Trichoderma- enriched biofertilizer $15 \mathrm{t} / \mathrm{ha}, \mathrm{T}_{4}=$ Farmyard manure $5 \mathrm{t} / \mathrm{ha}, \mathrm{T}_{5}=$ Farmyard manure $10 \mathrm{t} /$ ha and $\mathrm{T} 6=$ Farmyard manure $15 \mathrm{t} / \mathrm{ha}$ ).

All the macronutrients contents increased in stem, leaf and fruit over control in response to different treatments (Table 3). The increases were statistically significant for all the nutrients except for Ca content in stem and leaf. $\mathrm{N}, \mathrm{S}$ and $\mathrm{Mg}$ content in stem and leaf of brinjal plants ranged from $1.01-1.71,0.27-0.45$ and $0.18-0.38 \%$ where the maximum content was found in $\mathrm{T}_{3}$ treatment; the increases were almost 69,67 and $111 \%$ over control, respectively. Following the similar trend, N, P, S and Mg content in fruit of 
brinjal plant ranged from $1.15-2.27,0.21-0.59,0.33-0.48$ and $0.07-0.20 \%$ where maximum content was found in $\mathrm{T}_{3}$ treatment. The contents increased by almost 97, 181, 45 and $186 \%$ over control, respectively. The fact that $\mathrm{T}_{3}$ treatment gave the highest yield can be attributed to the higher content of all the nutrients in the Trichoderma-enriched biofertilizer than farmyard manure (Table 1).

Table 3. Macronutrient contents in brinjal in response to different treatments.

\begin{tabular}{|c|c|c|c|c|c|c|c|c|c|c|c|c|}
\hline \multirow[b]{3}{*}{$\begin{array}{c}\text { Treat- } \\
\text { ment }\end{array}$} & \multicolumn{12}{|c|}{ Macronutrient contents (\%) } \\
\hline & \multicolumn{2}{|c|}{$\mathrm{N}$} & \multicolumn{2}{|c|}{$\mathrm{P}$} & \multicolumn{2}{|c|}{$\mathrm{K}$} & \multicolumn{2}{|c|}{$\mathrm{S}$} & \multicolumn{2}{|c|}{$\mathrm{Ca}$} & \multicolumn{2}{|c|}{$\mathrm{Mg}$} \\
\hline & $\begin{array}{c}\text { Stem, } \\
\text { leaf }\end{array}$ & Fruit & $\begin{array}{c}\text { Stem, } \\
\text { leaf }\end{array}$ & Fruit & $\begin{array}{c}\text { Stem, } \\
\text { leaf }\end{array}$ & Fruit & $\begin{array}{c}\text { Stem, } \\
\text { leaf }\end{array}$ & Fruit & $\begin{array}{c}\text { Stem, } \\
\text { leaf }\end{array}$ & Fruit & $\begin{array}{c}\text { Stem, } \\
\text { leaf }\end{array}$ & Fruit \\
\hline $\mathrm{T}_{0}$ & 1.01 & 1.15 & 0.31 & 0.21 & 1.51 & 1.37 & 0.27 & 0.33 & 2.51 & 0.20 & 0.18 & 0.07 \\
\hline $\mathrm{T}_{1}$ & 1.21 & 1.52 & 0.45 & 0.53 & 2.5 & 2.84 & 0.29 & 0.38 & 4.13 & 0.62 & 0.32 & 0.13 \\
\hline $\mathrm{T}_{2}$ & 1.68 & 1.98 & 0.4 & 0.52 & 2.89 & 3.93 & 0.35 & 0.44 & 3.25 & 0.45 & 0.26 & 0.14 \\
\hline $\mathrm{T}_{3}$ & 1.71 & 2.27 & 0.49 & 0.59 & 3.1 & 3.44 & 0.45 & 0.48 & 3.16 & 0.59 & 0.38 & 0.20 \\
\hline $\mathrm{T}_{4}$ & 1.47 & 1.19 & 0.37 & 0.36 & 1.85 & 2.13 & 0.27 & 0.35 & 2.58 & 0.29 & 0.21 & 0.12 \\
\hline $\mathrm{T}_{5}$ & 1.09 & 1.67 & 0.46 & 0.44 & 2.63 & 2.98 & 0.31 & 0.41 & 2.75 & 0.33 & 0.27 & 0.12 \\
\hline T6 & 1.44 & 1.27 & 0.53 & 0.46 & 3.5 & 3.56 & 0.39 & 0.44 & 3.23 & 0.41 & 0.29 & 0.16 \\
\hline $\begin{array}{c}\text { LSD at } \\
5 \%\end{array}$ & 0.15 & 0.29 & 0.10 & 0.10 & 0.18 & 0.43 & 0.09 & 0.10 & NS & 0.21 & 0.09 & 0.05 \\
\hline
\end{tabular}

$\mathrm{T}_{1}, \mathrm{~T}_{2}, \mathrm{~T}_{3}, \mathrm{~T}_{4}, \mathrm{~T}_{5}$ and $\mathrm{T}_{6}$ are same as in Table 2.

On the other hand, P, K, Ca content in stem and leaf of brinjal plants ranged from $0.31-0.53,1.51-3.50$ and $2.51-4.13 \%$ where the maximum content was found in $\mathrm{T}_{6}, \mathrm{~T}_{3}$ and $\mathrm{T}_{1}$ treatments, respectively. In case of fruit, the maximum $\mathrm{K}$ and $\mathrm{Ca}$ content was found in $T_{2}$ and $T_{1}$ rather than $T_{3}$. These results indicate that differential uptake of $P$ may occur in brinjal where Trichoderma-enriched biofertilizer supplies high amount of $\mathrm{P}$ to fruit but not to stem and leaf whereas reverse may occur in case of farmyard manure. $\mathrm{K}$ uptake also may be affected by Trichoderma-enriched biofertilizer. Studies have found that some macronutrients $(\mathrm{P}, \mathrm{K}$ and $\mathrm{Ca}$ ) and micronutrients $(\mathrm{Zn}$ and $\mathrm{Fe}$ ) become more available due to Trichoderma application ${ }^{(15)}$.

All the micronutrients contents increased over control in response to different treatments in stem, leaf and fruit (Table 4). These increases were statistically significant for all the nutrients. The highest contents of $\mathrm{Mn}, \mathrm{Zn}$ and $\mathrm{Na}$ in stem, leaf and fruit of brinjal plants were recorded in treatment $\mathrm{T}_{3}$ and the highest content of $\mathrm{Fe}$ in $\mathrm{T}_{4}$ and $\mathrm{T}_{6}$ since Fe content was higher in farmyard manure. The fruit yield was found to highly correlate with $\mathrm{N}(\mathrm{r}=0.87), \mathrm{P}(\mathrm{r}=0.82), \mathrm{S}(\mathrm{r}=0.95), \mathrm{Mg}(\mathrm{r}=0.91), \mathrm{Mn}(\mathrm{r}=0.96), \mathrm{Zn}(\mathrm{r}=$ $0.82)$, and $\mathrm{Na}(\mathrm{r}=0.94)$ content. But poor correlations were seen with $\mathrm{K}, \mathrm{Ca}$ and Fe.

Post-harvest soil analysis showed that all the physico-chemical properties of soil remained more or less same or in some cases (i.e., $\mathrm{pH}$, EC) improved after Trichoderma and farmyard manure application and crop removal (Table 5). Compared to farmyard manure Trichoderma increased soil organic carbon $(\mathrm{OC})$, nitrogen $(\mathrm{N})$ and phosphorus $(\mathrm{P})$ 
availability. There were no harmful buildup of $\mathrm{Na}$ or Fe content in soil due to application of either.

Table 4. Micronutrient contents in brinjal in response to different treatments.

\begin{tabular}{ccccccccc}
\hline & \multicolumn{8}{c}{ Micronutrient contents $(\mathrm{mg} / \mathrm{kg})$} \\
\cline { 2 - 9 } Treatments & \multicolumn{2}{c}{ Fe } & \multicolumn{3}{c}{ Mn } & \multicolumn{3}{c}{ Na } \\
\cline { 2 - 9 } & Stem, & Fruit & Stem, & Fruit & Stem, & Fruit & Stem, & Fruit \\
\cline { 2 - 9 } & leaf & \multicolumn{3}{c}{ leaf } & leaf & leaf & \\
\hline $\mathrm{T}_{0}$ & 154.6 & 24.9 & 28.8 & 7.0 & 59.1 & 19.0 & 663.3 & 367.4 \\
$\mathrm{~T}_{1}$ & 184.7 & 28.6 & 44.8 & 8.8 & 86.1 & 35.8 & 826.5 & 408.2 \\
$\mathrm{~T}_{2}$ & 194.9 & 34.7 & 65.2 & 10.8 & 99.3 & 29.9 & 887.8 & 486.8 \\
$\mathrm{~T}_{3}$ & 213.3 & 35.1 & 90.7 & 15.0 & 127.0 & 39.4 & 959.2 & 583.7 \\
$\mathrm{~T}_{4}$ & 393.4 & 49.6 & 34.6 & 8.1 & 59.3 & 21.8 & 653.1 & 387.8 \\
$\mathrm{~T}_{5}$ & 324.1 & 54.4 & 29.9 & 9.0 & 80.1 & 23.5 & 775.5 & 408.2 \\
$\mathrm{~T}_{6}$ & 209.3 & 68.5 & 30.4 & 9.2 & 88.9 & 28.1 & 887.8 & 520.4 \\
LSD at 5\% & 49.54 & 7.93 & 7.80 & 2.56 & 7.49 & 4.44 & 56.94 & 69.74 \\
\hline
\end{tabular}

$\mathrm{T}_{1}, \mathrm{~T}_{2}, \mathrm{~T}_{3}, \mathrm{~T}_{4}, \mathrm{~T}_{5}$ and $\mathrm{T}_{6}$ are same as in Table 2.

Table 5. Post-harvest changes in soil properties after different treatments.

\begin{tabular}{cccccccccccccc}
\hline & $\mathrm{pH}$ & $\mathrm{EC}$ & $\mathrm{OC}$ & $\mathrm{N}$ & $\mathrm{P}$ & $\mathrm{K}$ & $\mathrm{S}$ & $\mathrm{Ca}$ & $\mathrm{Mg}$ & $\mathrm{Fe}$ & $\mathrm{Mn}$ & $\mathrm{Zn}$ & $\mathrm{Na}$ \\
\hline & & $(\mu \mathrm{S} / \mathrm{cm})$ & $(\%)$ & & & & \multicolumn{2}{c}{$(\mathrm{mg} / \mathrm{kg})$} & & & & \\
\hline $\mathrm{In}$ & 6.2 & 311 & 1.05 & 162.92 & 27.52 & 106.7 & 24.7 & 1247 & 195.5 & 66.92 & 28.86 & & 51.32 \\
\hline $\mathrm{T}_{0}$ & 7.49 & 109.8 & 0.85 & 34.3 & 14.89 & 76.75 & 14.97 & 1003 & 156.9 & 33.9 & 5.74 & 1.34 & 43.89 \\
$\mathrm{~T}_{1}$ & 7.4 & 110.2 & 0.98 & 41.16 & 15.56 & 86.74 & 16.33 & 1013 & 158 & 34.98 & 7.56 & 2.46 & 50.4 \\
$\mathrm{~T}_{2}$ & 7.29 & 125 & 1.29 & 63.11 & 20.92 & 116.7 & 17.52 & 1233 & 165.6 & 35.51 & 7.75 & 2.93 & 49.87 \\
$\mathrm{~T}_{3}$ & 7.17 & 147 & 1.33 & 63.11 & 28.43 & 106.7 & 19.22 & 1348 & 167.4 & 37.82 & 8.96 & 3.61 & 52.67 \\
$\mathrm{~T}_{4}$ & 7.43 & 117.5 & 1.04 & 38.95 & 14.95 & 96.73 & 15.65 & 1058 & 160.7 & 36.43 & 5.89 & 1.96 & 48.8 \\
$\mathrm{~T}_{5}$ & 7.34 & 119.1 & 1.21 & 41.16 & 16.71 & 106.7 & 14.62 & 1206 & 157.9 & 38.88 & 6.37 & 2.46 & 45.09 \\
$\mathrm{~T}_{6}$ & 7.21 & 135 & 1.19 & 54.88 & 17.67 & 96.73 & 17.86 & 1297 & 163.4 & 38.95 & 7.29 & 2.49 & 47.08 \\
\hline
\end{tabular}

In = Initial soil, $\mathrm{T}_{1}, \mathrm{~T}_{2}, \mathrm{~T}_{3}, \mathrm{~T}_{4}, \mathrm{~T}_{5}$ and $\mathrm{T}_{6}$ are same as in Table 2.

The experimental results revealed that Trichoderma-enriched biofertilizer can be added for better growth and yield of brinjal as they performed very well in increasing the growth and yield parameters (plant height, fruit length, fresh weight and dry weight of stem \& leaf and fruit) of brinjal plant. In comparison to farmyard manure Trichodermaenriched biofertilizer proved to be more effective in terms of yield.

\section{References}

1. El-Lithy M, N El-Batanony, S Moreno and E Bedmar 2014. A selected rhizobial strain isolated from wild grown Medicago monspeliaca improves productivity of non-specific host Trifolium alexandrinum. Applied Soil Ecology 73: 134-139.

2. Samman S, JWY Chow, MJ Foster, ZI Ahmad, JL Phuyal and P Petocz 2008. Fatty acid composition of edible oils derived from certified organic and conventional agricultural methods. Food Chemistry 109: 670-674. 
3. Benitez T, MA Rincon, MC Limon and CA Codon 2004. Biocontrol mechanisms of Trichoderma strains. International Microbiology 7: 249-260.

4. Tonfack LB, A Bernadac, E Youmbi, VP Mbouapouognigni, M Ngueguim, and A Akoa 2009. Impact of organic and inorganic fertilizers on tomato vigor, yield and fruit composition under tropical soil conditions. Fruits 64: 167-177.

5. Srinivasan U, HJ Staines and A Bruce 1992. Influence of media type on an antagonistic modes of Trichoderma spp. against wood decay basidiomycetes. Materialist Organismen 27: 301-321

6. Kapri A and L Tewari 2010. Phosphate solubilization potential and phosphatase activity of rhizospheric Trichoderma spp. Brazilian Journal of Microbiology 41(3): 787-795.

7. Khan NI, AU Malik, F Umer and MI Bodla 2010. Effect of tillage and farmyard manure on physical properties of soil. International Research Journal of Plant Science 1(4): 75-82.

8. Akter F 2016. Remediation of acid and calcareous soils-VI: Effects of Trichoderma enriched biofertilizer and farmyard manure on the growth and yield of brinjal grown in the manipulated soil. MS thesis, Dhaka University, Bangladesh.

9. BARC (Bangladesh Agriculture Research Council) 2012. Fertilizer Recommendation Guide. Soils Publication. 45: 7-35.

10. Jackson ML 1973. Soil Chemical Analysis. Prentice Hall Inc., Englewood Cliffs, New Jersy, USA. pp. 1-498.

11. Adams P, FA De-Leij and JM Lynch 2007. Trichoderma harzianum Rifai 1295-22 mediates growth promotion of cracl willow (Salix fragilis) samplings in both clean and metal contaminated soil. Microbial Ecology 54(2): 306-313

12. Agbo CU, PU Chukwudi and AN Ogbu 2012. Effects of rates and frequency of application of organic manure on growth, yield and biochemical composition of Solanum melongena L. (cv. 'Ngwa local') fruits. Journal of Animal and Plant Sciences 14(2): 1952-1960.

13. Altomare C, WA Norvell, T Bjorkman and GE Harman 1999. Solubilization of phosphate and micronutrients by the plant growth promoting and biocontrol fungus Trichoderma harzianum Rifai 1295-22. Applied Environmental Microbiology 65: 2926-2933.

14. Inbar J, M Abramsky and I Chet 1994. Plant growth enhancement and disease control by Trichoderma harzianum in vegetable seedlings under commercial conditions. European Journal of Plant Pathology 100: 337-346.

15. Cuevas VC 2006. Soil Inoculation with Trichoderma pseudokoningii Rifai enhances yield of rice. Philippine Journal of Science 135(1): 31-37. 